\title{
The Impact of Remuneration on the Organizational Commitment in the Mexican Context
}

\author{
Rosalba Treviño Reyes \\ Universidad Autónoma de Nuevo León \\ Adriana Segovia Romo \\ Universidad Autónoma de Nuevo León \\ Elías Alvarado Lagunas \\ Universidad Autónoma de Nuevo León
}

\begin{abstract}
Organizational commitment is one of the 18 competencies most demanded by employers for a good performance at a professional level. The most worrisome is that studies show that close to $80 \%$ of the employees in each company are not committed to their work. In this paper, remunerations, psychological empowerment and organizational commitment are reviewed. The objective is to analyze the current context of the problem, the theoretical perspectives of the literature on these variables, and to propose a graphic model subject of study that would be the beginning of a future empirical investigation.
\end{abstract}

Keywords: Remunerations, Psychological Empowerment, Organizational Commitment

\section{INTRODUCTION}

The world of work is constantly evolving. Social changes, consumption habits, new technologies, the economic crisis, political decisions and globalization are factors that influence the labor market. Currently, work needs to have a special meaning for people, considering factors such as quality of life and personal growth to make the decision to stay there or not. When working conditions become complicated, various problems arise that affect organizations, but especially their workforce.

A concept that has grown in organizational psychology, and focuses on studying the links that are generated between employees and the organization is organizational commitment, which has a direct effect on employee attitudes and behavior, since it allows job stability and guarantees to cover both material and psychological needs, benefiting the families and the economy of the country (Betanzos and Paz, 2007). A study conducted by Gallup identified three types of employees in the organizations: committed employees, non-committed employees and actively non-committed employees (Arias, 2019). The report shows a worrying reality: $79 \%$ of the employees in each company are not committed to their work. Organizations today are trying to achieve 100\% of their results in a highly competitive 
environment, full of threats and obstacles and they do so with only $21 \%$ of their employees committed and focused on their position (Arias, 2019).

At present, working conditions determine positive psychological states and work well-being. In Mexico, many organizations are known for giving insufficient rewards to their members, as indicated by the fact that this country does not occupy the first places in a world ranking of average salaries. It can be said then that Mexican workers develop their activities in a precarious environment, which limits their ability to identify with the organization and adapt to the work role, decreasing their productivity and obtaining job satisfaction (Calderón, Laca, Pando and Pedroza, 2015).

Among the contextual background highlights that Deloitte (2017) published in its fifth global survey on millennials, it showed that $66 \%$ prefer flexible work schemes to increase commitment, health, happiness and to achieve the objectives of the organization. A study by Glassdoor revealed that the main indicator of job satisfaction is not the salary, but the culture and values of the organization, as well as the leadership quality of managers, and career opportunities (Rodríguez, 2018). In the trends of the labor market in Mexico for 2019, the economic remuneration ceased to be the most important aspect for employees; the culture and values of the organization are preferred, as well as having feedback from managers, career opportunities, and empowerment, among other factors (Rodríguez, 2018).

A study carried out by the Organization for Economic Cooperation and Development (OECD) showed that organizational commitment is one of the 18 competencies most demanded by employers for good professional performance (Cortés, 2018). It has taken interest in its study and analysis in recent decades in such a way that its definition has been enriched from different points of view (Villa and Márquez, 2016).

In addition to this, employees demand compensation or compensation systems that they perceive are fair and proportional to their abilities and expectations. Payment is an important consideration in the administration of human resources because it offers employees a tangible reward for their services, as well as a source of recognition and sustenance (Villanueva and González, 2005). In addition, Molina (2006) points out that the term empowerment means enabling, granting, allowing an initiative to a certain person to act by itself and encourage initiative in others. Empowerment is synonymous with a culture of participation that requires the participation of all to achieve quality objectives. This term is made up of two variants: group and individual.

Based on this, the initiative arises to study factors that impact on the organizational commitment in an organization, but not only in companies, but also in the educational context, where it is so important, since most teachers carry out their work not only in the classroom but outside of it, where time is necessary to optimize it and go beyond the economic benefits that may be received.

In this population segment of teachers there is still an epistemological vacuum that is not covered in terms of the relationships of the concepts presented previously, so that its study becomes transcendent. The main objective of this work is to present the results of a theoretical review of the concepts related to remuneration, psychological empowerment and organizational commitment from different perspectives and levels of analysis; later, to propose a graphic model subject of study in a future empirical research applied to teachers of upper secondary education.

\section{THEORETICAL FRAMEWORK}

The success of an organization obeys, to a great extent, human relations, and these in turn depend on attitudinal variables such as the case of organizational commitment, which is associated with organizational results: performance, absenteeism, turnover personal, among others. It has been given special attention since the $50 \mathrm{~s}$ by numerous researchers in the workplace highlighting the strong relationship between the commitment and the decision to leave the organization by the worker (Maldonado-Radillo, Guillén and Carranza, 2012).

The classic authors who have defined organizational commitment have done so from different perspectives. From the "perspective of social exchange", commitment is the link that the individual establishes with their organization, fruit of the small investments made over time; that is, the person 
continues in the organization because changing their situation would mean sacrificing the investments made (Becker, 1960, cited in Betanzos and Paz, 2007). In the "psychological perspective," it is defined as the relative strength of individual identification and involvement with a particular organization (Mowday, Steers, and Porter, 1979, cited in Betanzos and Paz, 2007). From the "perspective of attribution", it is an obligation that the individual acquires as a result of performing certain acts that are voluntary, explicit and irrevocable (Reichers, 1985, cited in Betanzos and Paz, 2007).

There are many definitions and theories about commitment that have been historically stated, although it may be that provided by Meyer and Allen, one of the most developed in recent years (Neininger and Lehmann-Willenbrock, 2010; McInnis, Meyer and Feldman, 2009). . These authors understood the term commitment as a psychological state that characterizes the relationship between a person and an organization, proposing a three-dimensional model of it (affective, continuity and normative). It is the degree to which people identify, are consubstantial with their organizations and willing to continue working on them (Allen and Meyer, 1996). Assessing the organizational commitment from the three possible feelings an employee experiences (affective, continuity and normative) provides the opportunity to obtain more complete results by defining the type of commitment they experience and predicting their possible reaction to certain stimuli (Ríos, Rayo and Ferrer, 2010).

On the other hand, remunerations are considered as the payment that the employee receives for his labor in economic terms (Rubio and Piatti, 2000). Diomede (2008) explains that compensation is a key system for organizations as long as it is based on equity. For Villanueva and González (2005) these include base remuneration, incentives and benefits. For some authors, remunerations are the most important motivator for the workforce to feel satisfied and motivated, which can be related to psychological empowerment. Westerman, Beekun, Daily and Vanka (2009) identified the organizations' search for new forms of compensation that allow them to adapt to the current world. Martín, N., Hernangómez and Martín, V. (2007) recommend that the compensations be equal to the contributions; so that having enough income to compensate all those involved, a satisfaction is achieved, making the organization reach equilibrium. Segovia (2014) found a non-significant relationship between variable compensation and psychological empowerment. As it is analyzed, there is little or no existence of articles that specifically relate the remunerations variable with the psychological empowerment in an exact or direct way, and even with the organizational commitment.

Conger and Kanungo (1988) explain that empowerment in their individual form is considered a provocative element to stimulate workers, rather than a simple delegation of power, creating the conditions to increase motivation in the execution of tasks through the development of a strong sense of personal efficacy. The psychological empowerment is the increase of the intrinsic motivation in the performance of the function, from four concepts: meaning of the task, competence, self-determination, and impact, which orient the focus of the individual towards the performance of his function, emphasizing that psychological empowerment is not a characteristic of the personality, rather it is a set of cognitions defined based on a certain work context (Thomas and Velthouse, 1990, Spreitzer, 1995). Several studies have linked psychological empowerment with organizational commitment (Ríos et al., 2010, Chiang, Valenzuela and Lagos, 2014, Segovia, 2014), explaining that the relationship between these variables is a field little explored from the organizational perspective.

When reviewing the literature, it is found that psychological empowerment has been studied as a mediating variable with organizational commitment, such is the case of Segovia's research (2014) whose model had as independent variables transformational leadership and variable compensation, and as dependent variables job satisfaction, organizational commitment and teamwork within the construct of attitudinal results. On the other hand, Chang, Shih and Lin (2010) tested an exploratory model of empowerment in a Taiwanese sample of school health nurses by testing the mediating role of psychological empowerment in the relationship between external factors and work-related attitudes, specifically job satisfaction and organizational commitment.

In addition, O'Brien's research (2010) shows the psychological empowerment as a mediating variable between structural empowerment and burnout in nurses. Other studies have shown the mediating role of psychological empowerment between the structural characteristics of the workplace (for example, access 
to resources and information and organizational culture) and positive organizational results such as innovation, job satisfaction, performance and efficiency (Bonias, Bartram, Leggat and Stanton, 2010; Randolph and Edward, 2011).

\section{METHODS}

For the purposes of this paper, a bibliographical research was carried out based on the existing literature on remuneration, psychological empowerment and organizational commitment in various contexts, fundamental aspects of the study of human capital in organizations. In addition, the organizational commitment and the main concepts associated with it were explored under a qualitative approach.

With a descriptive scope (Hernández et al., 2016), this article reviewed the different theories related to the variables to be studied, and based on them were included the definitions, empirical relationships and conclusions of the independent, dependent and mediating constructs that correspond to the what, how and why, respectively, essential elements of the theory according to Whetten (1989). The theoretical analysis is concluded with a graphical model and research hypothesis to be proposed for a future empirical study applied to teachers of upper secondary education in Mexico.

\section{RESULTS}

Based on previous empirical studies related to the variables of this work, a theoretical perspective was delimited considering the present investigation, as part of a more extensive future investigation. Given this, it was possible to emphasize the study of organizational commitment, as an attitude variable that leads to success in an organization (Maldonado-Radillo, Guillén and Carranza, 2012). Although it has been studied since the middle of the last century, it is Allen and Meyer (1996) who consider it as the degree to which people identify, are consubstantial with their organizations and willing to continue working on them.

At the same time, empowerment is one of the terms that has been analyzed from various areas such as sociology, education, psychology, social work and organizational. Although it emerged in the 60's, it expanded a decade later with Kanter (1977) who introduced it into the workplace. The concept admits a double reading: psychological empowerment and structural empowerment. In the nineties, psychological empowerment became important, where Thomas and Velthouse (1990) and Spreitzer (1995) explained it as the increase of an individual's motivation by itself based on the meaning, competence, selfdetermination and impact of the execution of one's work. Several studies have linked psychological empowerment with organizational commitment (Ríos et al., 2010, Chiang, Valenzuela and Lagos, 2014, Segovia, 2014).

Although the literature found shows incipient features of correlations between psychological empowerment and organizational commitment, it was not possible to find empirical relationships that demonstrate the positive relationship between remunerations and psychological empowerment, impacting on organizational commitment; therefore, there is an interest in landing the study of these variables jointly in the teaching context, in one of the professions with greater workload inside and outside the classroom, essentially the degree commitment that teachers must have to achieve great results, beyond the economic benefits they receive.

Psychological empowerment will be used as a mediating variable between remunerations and organizational commitment, being interesting to know the impact between these variables and their effect on the teachers to be studied. Therefore, it is a third variable, that is, an intervening variable that affects the relationship between two variables, where the independent variable and the potentially mediating variable influence the dependent variable (Baron and Kenny, 1986, Hayes, 2013).

From the review of literature and the empirical relationships found by various authors, the proposal of the following model is made (figure 1) and hypotheses that will be subject of research in future work: 


\section{FIGURE 1 \\ PROPOSED GRAPHIC MODEL}

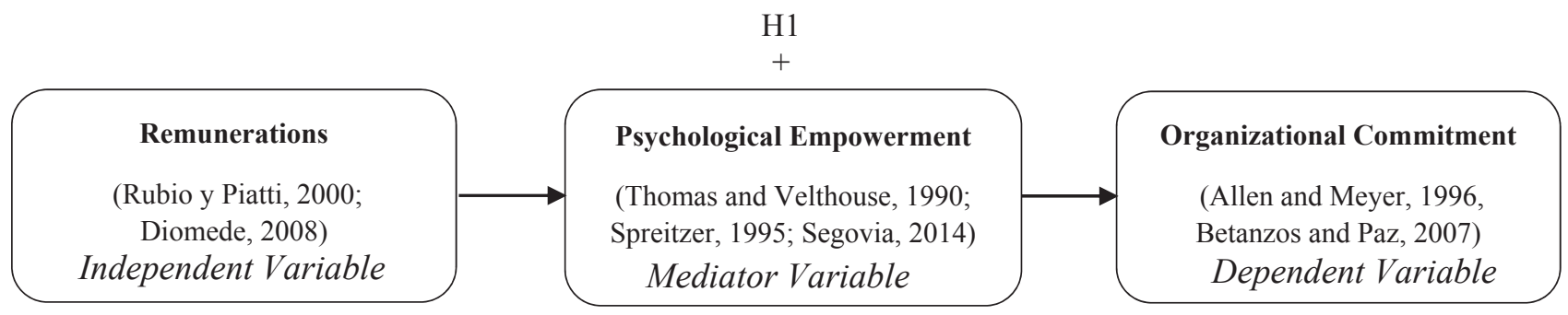

Source: Prepared by the author

\section{Hypothesis Proposal}

H1. Remunerations have a positive impact on the organizational commitment through the psychological empowerment of teachers in public institutions of upper secondary education.

Considering the review of the literature, the contributions to the existing epistemological vacuum and the methodological challenges it represents, the research model presented is proposed, where the relationships between remuneration, psychological empowerment and organizational commitment in teachers in public educational institutions could be studied. upper middle level in Mexico. Considering the criteria of Creswell (2015) in its model of deficiencies in the literature, this research will contribute with the contribution of knowledge in various theoretical gaps since authors have not studied about certain proposed variables; few scientific studies have been found in Mexico, where it is probable that the model proposed in this study has not been specifically studied before. The research would focus on teachers of higher secondary education, a field studied little empirically (Barraza, 2008), to look for strategies that contribute to the development of more committed teachers.

\section{CONCLUSIONS}

In this work we analyzed the different theories related to the study to be carried out and included the definitions, relationships and conclusions of the proposed variables corresponding to what, how and why, respectively, essential elements of the theory according to Whetten (1989). The results section is concluded with the proposal of the graphic model and the research hypothesis. In accordance with the theoretical foundations of the variables under study, an academic reflection and debate of the scientific theories that support them was carried out, being one of the contributions to the existent epistemological vacuum in this subject regarding its study in this country, in the population and area selected to investigate (Creswell, 2015).

According to the analysis of the literature review, remunerations could have a positive impact with organizational commitment through psychological empowerment, making employees more committed, satisfied, with well-being and personal fulfillment, both in profit and welfare organizations. Currently, the management of human capital has emphasized its studies on the organizational behavior of the workforce, bringing with it great results, where working conditions determine positive psychological states and work well-being, which makes the investigation of these issues in teachers important. of upper secondary education, a population segment little studied empirically (Barraza, 2008).

According to the theoretical review analyzed, the knowledge gaps considered and the methodological challenges presented, the aforementioned research model is proposed. A complete future investigation, through the application of questionnaires and the analysis and interpretation of the results, will allow these institutions to design strategies, based on remunerations but supported by intrinsic motivations such as psychological empowerment, so that teachers feel supported in multiple aspects, bringing with it an 
increase in commitment to their work area, in one of the professions with greater workload inside and outside the classroom, essentially the degree of well-being that teachers have in their institutions and the way in which they support them .

Based on the above, the objective of this paper was to present the result of a theoretical review of the concepts associated with remuneration, psychological empowerment and organizational commitment, considering different perspectives and levels of analysis, and then propose a model graphic subject of study in a future empirical research applied to teachers of upper secondary education. Finally, the results and conclusions that continue to the field research of this study will be reflected in a future work subject of publication.

\section{REFERENCES}

Allen, N., \& Meyer, J. (1996). Affective, continuance and normative commitment to the organization: An examination of construct validity. Journal of Vocational Behavior, 49, 252-276.

Arias, A. (2019). Compromiso. El horizonte. Retrieved from http://www.elhorizonte.mx/opinion/editorial/compromiso/2444513.

Baron, R. M., \& Kenny, D. A. (1986). The moderator-mediator variable distinction in social psychological research: Conceptual, strategic and statistical considerations. Journal of Personality and Social Psychology, 51, 1173-1182.

Barraza, A. (2008). Compromiso organizacional docente. Un estudio exploratorio. Avances en Supervisión Educativa, 8, Asociación de Inspectores de Educación en España.

Betanzos, N., \& Paz, F. (2007). Análisis psicométrico del compromiso organizacional como variable actitudinal. Anales de psicología, 23(2), 207-215.

Bonias, D., Bartram, T., Leggat, S., \& Stanton, P. (2010). Does psychological empowerment mediate the relationship between high performance work systems and patient care quality in hospitals? Asia Pacific Journal of Human Resources, 48(3), 319337. http://dx.doi.org/10.1177/10384411110381667.

Calderón, J., Laca, F., Pando, M., \& Pedroza, F. (2015). Relación de la socialización organizacional y el compromiso organizacional en trabajadores mexicanos. Psicogente, 18(34), 267-277. http://doi.org/10.17081/psico.18.34.503.

Chang, L., Shih, C., \& Lin, S. (2010). The mediating role of psychological empowerment on job satisfaction and organizational commitment for school health nurses: A cross-sectional questionnaire survey. International Journal of Nursing Studies, 47(4), 427-433.

Chiang, M.M., Valenzuela, L., \& Lagos, M.A. (2014, December). RELATIONSHIP BETWEEN PSYCHOLOGICAL EMPOWERMENT AND ORGANIZATIONAL COMMITMENT IN SMALL AND MEDIUM ENTERPRISES. Multidisciplinary Business Review, 7(1).

Conger, J., \& Kanungo, R. (1988). The empowerment process: Integrating theory and practice. Academy of Management Review, 13(3), 471-482.

Cortés, J. (2018). Which competencies are most in demand among employers around the world? Retrieved from http://observatory.itesm.mx/edu-bits-2/competencies-in-demand.

Creswell, J. W. (2015). Research Design: Qualitative, quantitative, and mixed method approaches. 4th. Edition. Thousand Oaks: Sage Publications.

Deloitte. (2017). Encuesta Millennials 2017. ¿Qué mundo quieren habitar? Retrieved from https://www2.deloitte.com/mx/es/pages/about-deloitte/articles/encuesta-millennial-2017.html.

Diomede, H. (2008). Compensaciones se escribe con " $E$ " de equidad. Retrieved from http://pt.slideshare.net/Diomede07/compensaciones-se-escribe-con-e-de-equidad.

Hayes, A.F. (2013). Introduction to Mediation, Moderation, and Conditional Process Analysis: A Regression-Based Approach. New York, NY: The Guilford Press.

Hernández, R., Fernández, C., \& Baptista, P. (2016). Metodología de la investigación. México, D.F.: McGraw Hill Interamericana Editores.

Kanter, R. M. (1977). Men and women of the corporation. New York: Basic Books. 
Maldonado-Radillo, S.E., Guillén, A.M., \& Carranza, R.E. (2012). El compromiso organizacional del personal docente y administrativos de una Universidad Pública. En Revista Internacional Administración \&Finanzas, 5(4), 135-142.

Martín, N., Hernángomez, J., \& Martín, V. (2007). El deleite de la eficiencia. Universia Business Review, 5(14), 56-67.

McInnis, Meyer, \& Feldman. (2009). Psychological contracts and their implications for commitment: A feature-based approach. Journal of Vocational Behavior, 74, 165-180.

Molina, R. (2006). Empowerment ¿actitud mental?, ¿técnica?, ¿estrategia? O ¿moda? México: Trillas.

Neininger, A., \& Lehmann-Willenbrock (2010). Effects of team and organizational commitment- A longitudinal study. Journal of vocational behaviour, 76, 567-579.

O'Brien, J. L. (2010). Structural empowerment, psychological empowerment and burnout in registered staff nurses working in outpatient dialysis centers (Doctoral dissertation, Rutgers UniversityGraduate School-Newark).

Randolph, W., \& Edward, R. (2011). Managerial use of power bases in a model of managerial empowerment practices and employee psychological empowerment. Journal of Leadership \& Organizational Studies, 18(1), 95-106.http://dx.doi.org/10.1177/1548051810379798.

Ríos, M., Rayo, M., \& Ferrer, J. (2010). El empowerment como predictor del compromiso organizacional en las Pymes. Contaduría y administración, 26(231), 103-125.

Rodríguez, K. (2018) Tendencias en el mercado laboral en México para 2019. Retrieved from http://computerworldmexico.com.mx/tendencias-en-el-mercado-laboral-en-mexico-para-2019/.

Rubio, V., \& Piatti, G.M. (2000). Manual de remuneraciones. Argentina: Cuyo.

Segovia, A. (2014). El liderazgo, la compensación variable, el empowerment psicológico y su impacto en la efectividad del empleado: un enfoque de modelación mediante ecuaciones estructurales (Doctoral dissertation, Universidad Autónoma de Nuevo León).

Spreitzer, G. M. (1995). Psychological Empowerment in the Workplace: Dimensions, Measurement, and Validation. The Academy of Management Journal, 38(5), 1442-1465.

Thomas, K., \& Velthouse, B. (1990). Cognitive Elements of Empowerment: An "Interpretive" Model of Intrinsic Task Motivation. Academy of Management Review, 15, 666-681. Retrieved from https://www.jstor.org/stable/258687?seq=1\#page_scan_tab_contents. DOI: 10.2307/258687.

Villa, O., \& Marquez, B. L. (2016). Relación del empowerment con el compromiso organizacional influenciado por el capital humano y prácticas de alto involucramiento de empleados en maquiladoras automotrices. In Global Conference on Business \& Finance Proceedings (Vol. 11, No. 1, p. 855). Institute for Business \& Finance Research.

Villanueva, A., \& González, E. (2005). Gestión en las compensaciones. Chile: Paidós.

Westerman, J.W., Beekun, R.I., Daily, J., \& Vanka, S. (2009). Personality and national culture. Predictors of compensation strategy preferences in the USA and India. Management Research News, 32(8), 767-781.

Whetten, D. A. (1989). What constitutes a theoretical contribution? Academy of management review, 14(4), 490-495.

100 Journal of Applied Business and Economics Vol. 21(5) 2019 